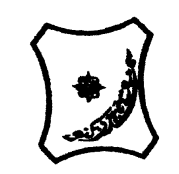

Bayero Journal of Pure and Applied Sciences, 12(1): 19 - 25

Received: May, 2018

Accepted: February, 2019

ISSN $2006-6996$

\title{
STUDIES ON PROXIMATE AND MINERAL CONTENTS OF EXTRUDED Nakiya FROM BLENDS OF RICE AND GROUNDNUT
}

\author{
${ }^{1}$ Jibril H., ${ }^{2}$ Filli K.B. and Adamu, M.A. \\ ${ }^{1,3}$ Department of Food Science and Technology, Wudil. Kano State, Nigeria \\ ${ }^{2}$ Department of Food Science and Technology, ModibboAdama University of Technology, Yola. \\ Adamawa State, Nigeria \\ Email address:hassanajibril24@gmail.com Phone no. + 2347031360462
}

\begin{abstract}
Nakiya which is a locally prepared snack was made from various blends of (90:10, 85:15 and 80:20) rice flour: groundnut paste, at moisture content of $18 \%, 20 \%$ and $22 \%$, by extruding at varied temperature of $80^{\circ} \mathrm{C}, 100^{\circ} \mathrm{C}$ and $120^{\circ} \mathrm{C}$. The Nakiya was extruded through a pilot scale co-rotating twin screw food extruder. The raw samples and extrudates were subjected to proximate and some minerals content determination. Moisture content, Ash and Fat, crude fiber and crude protein and minerals including Calcium, Sodium, Magnesium, Potassium and Phosphorus content were evaluated. It was found out that at 80: $20 \%$ substitution level of groundnut; protein, ash and fat were high. The products have a protein content of 7.54-12.27\%, a low moisture content of 2.83-10.33\%, low carbohydrate at $100^{\circ} \mathrm{C}$ and $120^{\circ} \mathrm{C}$ high temperature. The mineral were increased upon extruded at $80^{\circ}$ Cand at $20 \%$ level of groundnut substitution.
\end{abstract}

Key: Nakiya, proximate, mineral and twin screw extruder

\section{INTRODUCTION}

Snack has been defined as a portion of food eaten between meals, which come in varieties of forms; packaged and processed (Dictionary. Com,2011). Snack foods are often subjectively classified as junk food because they typically have little or no nutritional value, high in calorie, fat and low in proteins, vitamins and micronutrients, its serves calories satisfying short-term hunger and often eaten in a hurry (Ocheme et al., 2011). For the promotion of good health it is therefore recommending that people should make effort ineating more healthy snacks while avoiding low-nutrient junk food.

Nakiya is a cereal based traditional product made from rice. It can also be produce from maize flour with the use of honey instead of sugar, the honey and water need to be boiled followed with the addition of maize flour, as if one is going to prepare tuwonsemo, this type of Nakiya is common in areas like Adamawa, Taraba and Yobe States of Nigeria (Oral interview, 2014).

Most cereal/legumes in Northern Nigeria are processed traditionally as snacks like Dakuwa, Nakiya, Gugguru, Alkaki etc. Cereal grains are used for the production of different classes of foods; these include breakfast cereals such as corn flakes, breads, and pastries, brewing of both alcoholic and non-alcoholic drinks. Malting and extrusion methods have proven to increase the nutrient densities of many foods as well as means of processing traditional foods (Obatula, 2002).

Extrusion is a processing operation, which utilizes highly expanded, low-density products with unique textural properties which combines several units operations including mixing, cooking, kneading, shearing, shaping and forming to produce a product with unique characteristics (Riaz, 2013). The research aimed at determining the proximate composition and mineral content of Nakiya extrudate produced from various blends of rice and groundnut.

\section{MATERIALS AND METHODS}

\section{Samples Collection}

The materials used for this study are Groundnut, Rice, Ginger, Clove and sugar and were obtained from Jimeta Modern market, Yola, Nigeria.

Sample preparation

The rice flour was prepared by winnowing the rice, washing and drying, followed by milling using attrition mill modified method described by (Folake et al., 2015). 
BAJOPAS Volume 12 Number 1, June, 2019

The groundnut was also cleaned, roasted at $240^{\circ} \mathrm{C}$ for $30 \mathrm{~min}$; skins were removed by rubbing between palms, cooled, ground into paste by attrition mill(Ayo et al., 2012) with modifications. The spices which included ginger and clove were sorted, cleaned, dried and milled into powder using mortar and pestle, followed by sieving. Formulated flour (1.5 kg) of rice/groundnut paste at three levels of substitution with $150 \mathrm{~g}$ of ground sugar and $2 \mathrm{~g}$ of ginger were used in the production of Nakiya, extruded at varied temperature.

\section{Experimental Design}

A 3 factor 3 level $(3 \times 3 \times 3)$ full factorial experimental designswas use, in which 3 represent the feed moisture, 3 for barrel temperature and the last 3 represent the feed composition. The Experimental Layout was shown in Table 1.

\section{Analyses}

The moisture content, Ash, and Fat were determined by the AOAC method (2006), crude protein and crude fiber by AOAC (1990) while carbohydrate by difference, by the method of AOAC (2006).

Calcium, sodium, magnesium, potassium were determined by atomic absorption spectrophotometric method, while phosphorous was determined by AOAC (2000).

Table 1 Experimental Layout with the Coded and Natural Values

\begin{tabular}{|c|c|c|c|c|c|c|}
\hline \multirow[t]{2}{*}{ Design point } & \multicolumn{3}{|c|}{ Coded variables } & \multicolumn{3}{|c|}{ Natural values } \\
\hline & $\mathrm{X}_{1}$ & $\mathrm{X}_{2}$ & $x_{3}$ & $\mathrm{X}_{1}(\%)$ & $X_{2}(\%)$ & $\mathrm{X}_{3}\left({ }^{\circ} \mathrm{C}\right)$ \\
\hline 1 & 1 & 1 & 1 & 10 & 22 & 80 \\
\hline 2 & 1 & 1 & 2 & 10 & 20 & 80 \\
\hline 3 & 1 & 1 & 3 & 10 & 18 & 80 \\
\hline 4 & 1 & 2 & 1 & 10 & 18 & 100 \\
\hline 5 & 1 & 2 & 2 & 10 & 22 & 100 \\
\hline 6 & 1 & 2 & 3 & 10 & 20 & 100 \\
\hline 7 & 1 & 3 & 1 & 10 & 18 & 120 \\
\hline 8 & 1 & 3 & 2 & 10 & 20 & 120 \\
\hline 9 & 1 & 3 & 3 & 10 & 22 & 120 \\
\hline 10 & 2 & 1 & 1 & 15 & 20 & 80 \\
\hline 11 & 2 & 1 & 2 & 15 & 22 & 80 \\
\hline 12 & 2 & 1 & 3 & 15 & 18 & 80 \\
\hline 13 & 2 & 2 & 1 & 15 & 22 & 100 \\
\hline 14 & 2 & 2 & 2 & 15 & 20 & 100 \\
\hline 15 & 2 & 2 & 3 & 15 & 18 & 100 \\
\hline 16 & 2 & 3 & 1 & 15 & 18 & 120 \\
\hline 17 & 2 & 3 & 2 & 15 & 20 & 120 \\
\hline 18 & 2 & 3 & 3 & 15 & 22 & 120 \\
\hline 19 & 3 & 1 & 1 & 20 & 20 & 80 \\
\hline 20 & 3 & 1 & 2 & 20 & 22 & 80 \\
\hline 21 & 3 & 1 & 3 & 20 & 18 & 80 \\
\hline 22 & 3 & 2 & 1 & 20 & 20 & 100 \\
\hline 23 & 3 & 2 & 2 & 20 & 18 & 100 \\
\hline 24 & 3 & 2 & 3 & 20 & 22 & 100 \\
\hline 25 & 3 & 3 & 1 & 20 & 22 & 120 \\
\hline 26 & 3 & 3 & 2 & 20 & 20 & 120 \\
\hline 27 & 3 & 3 & 3 & 20 & 18 & 120 \\
\hline
\end{tabular}

The experiment was randomised. $\mathrm{X}_{1}=$ Feed composition $\mathrm{X}_{2}=$ Feed moisture content $\mathrm{X}_{3}=$ Barrel temperature

\section{RESULT AND DISCUSSION}

Proximate composition of raw samples, showed the moisture content ranges from $7.67-8.50 \%$, protein from $7.84-11.20 \%$, Fat with a value of
10.82-12.83, Ash have a value of 0.53-0.73, Fiber from $0.35-0.60$ while carbohydrate with a value of $66.14-72.79 \%$ as indicated in Table 2 


\begin{tabular}{lllllll}
\hline & \multicolumn{5}{c}{ Composition } & $(\%)$ \\
Samples & Moisture & Protein & Fat & Ash & Fiber & CHO \\
\hline A & $7.67 \pm 0.88^{\mathrm{ab}}$ & $7.84 \pm 0.5^{4 \mathrm{c}}$ & $10.82 \pm 1.96^{\mathrm{ab}}$ & $0.53 \pm 0.01^{\mathrm{c}}$ & $0.35 \pm 0.01^{\mathrm{c}}$ & $72.79 \pm 0.01^{\mathrm{a}}$ \\
B & $8.33 \pm 0.44^{\mathrm{ab}}$ & $9.64 \pm 0.01^{\mathrm{b}}$ & $11.63 \pm 4.14^{\mathrm{ab}}$ & $0.63 \pm 0.01^{\mathrm{b}}$ & $0.53 \pm 0.00^{\mathrm{b}}$ & $69.24 \pm 1.72^{\mathrm{b}}$ \\
C & $8.50 \pm 0.00^{\mathrm{a}}$ & $11.20 \pm 0.29^{\mathrm{a}}$ & $12.83 \pm 0.79^{\mathrm{a}}$ & $0.73 \pm 0.03^{\mathrm{a}}$ & $0.60 \pm 0.00^{\mathrm{a}}$ & $66.14 \pm 1.06^{\mathrm{c}}$ \\
\hline
\end{tabular}

Superscript represent level of significant at $5 \%$ across the column, superscripts with the same alphabets are not significant while those with different subscripts are significance at $5 \%$, where $a, b$ and $c$ designate the amount of the proximate composition as: $a>b>c$

Key: $A=90: 10$ (rice/groundnut Paste), $B=85: 15$ (rice/ groundnut paste), $C=80: 20$ (rice/ groundnut paste)

The results of the proximate analysis of the raw samples shows that the fat, protein and moisture content of flour blends tends to increase as the groundnut flour is added, that is sample B (15\% of groundnut) and C (20\% groundnut) had high fat, protein and moisture content in contrast with sample A (10 \% groundnut substitution) due to high in groundnut content as it is high in oil and protein
(Mukthar, 2009 and Ayoola et al. 2012). Sample A was found to be high in carbohydrate due to high rice content, which goes in line with the report of (Yousaf, 1992 ) and also cereals are generally high in carbohydrate (they store starch as source of energy). Alsofiber content increased with respect to the groundnutlevel substitution in the formulationat $20 \%$.



Fig 1 Proximate composition of extruded Nakiya 
BAJOPAS Volume 12 Number 1, June, 2019

The products were shown to have high level of carbohydrates content with a range of (69-6482.03) \%due to high rice content in the formulation, which goes with the report of James and Nwabeuze (2013), that carbohydrates can be reduced or increased upon extrusion, which depends on raw materials and extrusion variables. The carbohydrates were high in compared with the result of Oluwole et al. (2013).

In the protein content, the values varies significantly on the feed composition, temperature but insignificant on the moisture content of the feeds at $(P<0.05)$. At high groundnut level up to $20 \%$, high protein content were found in the products, with a ranged of $7.54 \pm 0.23$ to $12.27 \pm 0.00$ percent protein as depicted in table 3 . The result corresponds with the finding of Shivendraet al. (2007) that extrusion can adversely or otherwise improve protein content of products. Wani and Kumar (2015) and Nwabueze (2006) obtained high protein content in an extruded ready to eat snacks. The addition of legume to cereal enriches a product(Obatula, 2002 and Filliet al. 2012). The amount was slower than that of Oluwole et al. (2013) a value of 13.31 and 14.20 $\%$ of protein.

From table 3, the ash concentration range from 0.48-1.03\%. The Ash content of $1.03 \%$ was found in product with $80: 20$ rice/groundnut at $80^{\circ} \mathrm{C}$ while $0.48 \%$ from a product containing $90: 10$ ratio of rice/groundnut. This shows that at high groundnut level substitutions, ash content increases upon extrusion which agrees with Atasie et al. (2009) that ash content of groundnut was $3.8 \%$ greater than Ash content of rice.James and Nwabueze (2013), Filliet al. (2012) and Oluwoleet al.(2013) reported an increase in ash content of 2.85$5.15 \%, 1.7-2.0 \%$ and $13.31-14.20 \%$ from an extruded snacks respectively, though the values were high in disagree with $0.48-1.03 \%$ from this research, this might be due differences in substitution levels of feed composition and barrel temperature.

Extrudates have a fiber content of $0.24 \pm 0.23$ to $0.83 \pm 0.00$; high fibercontent in the products than in raw samples. The result obtained goes in line with the finding of Wani and Kumar (2015) where an increase in fiber content where found.

Fat content of the products were low in contrast to the raw samples, with a fat content of (4.77 $9.25 \%)$. High fat content were determined in products with high groundnut content of $20 \%$. Low fat in products with low levels of groundnut levels, the low fat content may beprobably due to the fact that lipids act as lubricant during extrusion (Guy, 2001).

A moisture content of $2.83 \%-10.33 \%$ was revealed which agrees with the report of Shivendraet al. (2007) thatextrudates usually have low moisture content of less than $15 \%$. Nwabueze (2006) obtained a moisture range of 4.00-5.80 \%. Dibyakantaet al. (2015) a moisture content of $12 \%$ and James and Nwabueze (2013) a reduced in moisture content from 21.00 to $9.70 \%$ in a snack, which is closer to the highest obtainable moisture of Nakiyaextrudate. All the moisture content mentioned were less than $15 \%$ asreported by Shivendra et al. (2007).

Table 3: Mineral Composition of Raw samples

\begin{tabular}{|c|c|c|c|c|c|}
\hline Samples & Calcium & $\begin{array}{r}\text { Mineral } \\
\text { Magnesium }\end{array}$ & $\begin{array}{l}(\mathrm{mg} / \mathrm{kg}) \\
\text { Sodium }\end{array}$ & Potassium & Phosphorus \\
\hline A & $70.83 \pm 0.07^{c}$ & $25.00 \pm 2.89^{b}$ & $8.33 \pm 0.88^{b}$ & $37.50 \pm 0.29^{b c}$ & $13.68 \pm 0.39^{c}$ \\
\hline B & $104.17 \pm 0.01^{\mathrm{a}}$ & $29.17 \pm 0.67^{\mathrm{a}}$ & $8.33 \pm 0.88^{\mathrm{b}}$ & $38.02 \pm 0.01^{\mathrm{b}}$ & $18.68 \pm 0.10^{\mathrm{a}}$ \\
\hline C & $75.00 \pm 5.77^{b}$ & $29.17 \pm 0.67^{\mathrm{a}}$ & $9.72 \pm 0.12^{\mathrm{a}}$ & $47.40 \pm 0.11^{\mathrm{a}}$ & $15.00 \pm 2.89^{b}$ \\
\hline
\end{tabular}

Superscript represent level of significant at $5 \%$, across the column, superscripts with the same alphabets are not significant while those with different subscripts are significance at $5 \%, a, b$ and represent the quality of minerals as $a>b>c$

Key

$A=90: 10$ (Rice: groundnut paste)

$\mathrm{B}=85: 15$ (Rice: groundnut paste)

$\mathrm{C}=80: 20$ (Rice: groundnut paste)

The result of the mineral content in (Table 3 ) of raw samples depicted high amount of Calcium in Sample B a value of $104.17 \mathrm{mg} / \mathrm{kg}$ (containing $15 \%$ groundnut) than in sample A and C. The value was lower than $440-1340 \mathrm{mg} / \mathrm{kg}$ of calcium depicted by Asibuo et al. (2008). 
BAJOPAS Volume 12 Number 1, June, 2019

High Magnesium content in sample B and C (samples having $15 \%$ and $20 \%$ groundnut) with a value of $29.17 \mathrm{mg} / \mathrm{kg}$ than A $(25.00 \mathrm{mg} / \mathrm{kg})$, probably due to high percentage level of groundnut in the blend, implying that groundnut contain more magnesium than rice as reported by Nuts, Healthy and Tasty (2011) and Asibuoet al. (2008).

Sample $\mathrm{C}$ had the highest amount of sodium $(9.72 \mathrm{mg} / \mathrm{kg})$ and potassium $(47.40 \mathrm{mg} / \mathrm{kg})$ than in $A$ and $B$, which was a sample with $20 \%$ groundnut, the high concentrations these minerals relates to the finding of (Mukthar,
2009). But in terms of phosphorus content sample B was with the highest value (18.68 $\mathrm{mg} / \mathrm{kg}$ ).

The study indicates that sample $C$ which is from a composition of $80: 20$ rice/groundnut flour is rich in Magnesium, sodium and potassium while Sample B (15 \%) was high in calcium and phosphorus than sample $A(10 \%$ of groundnut). This collaborates with the result of Asibuoet $a$. ./ 2008, Mukthar, 2009 and Ayoola et al. 2012). Variation exist in the mineral contents of the samples due to groundnut substitution and was significant at $(P<0.05)$.

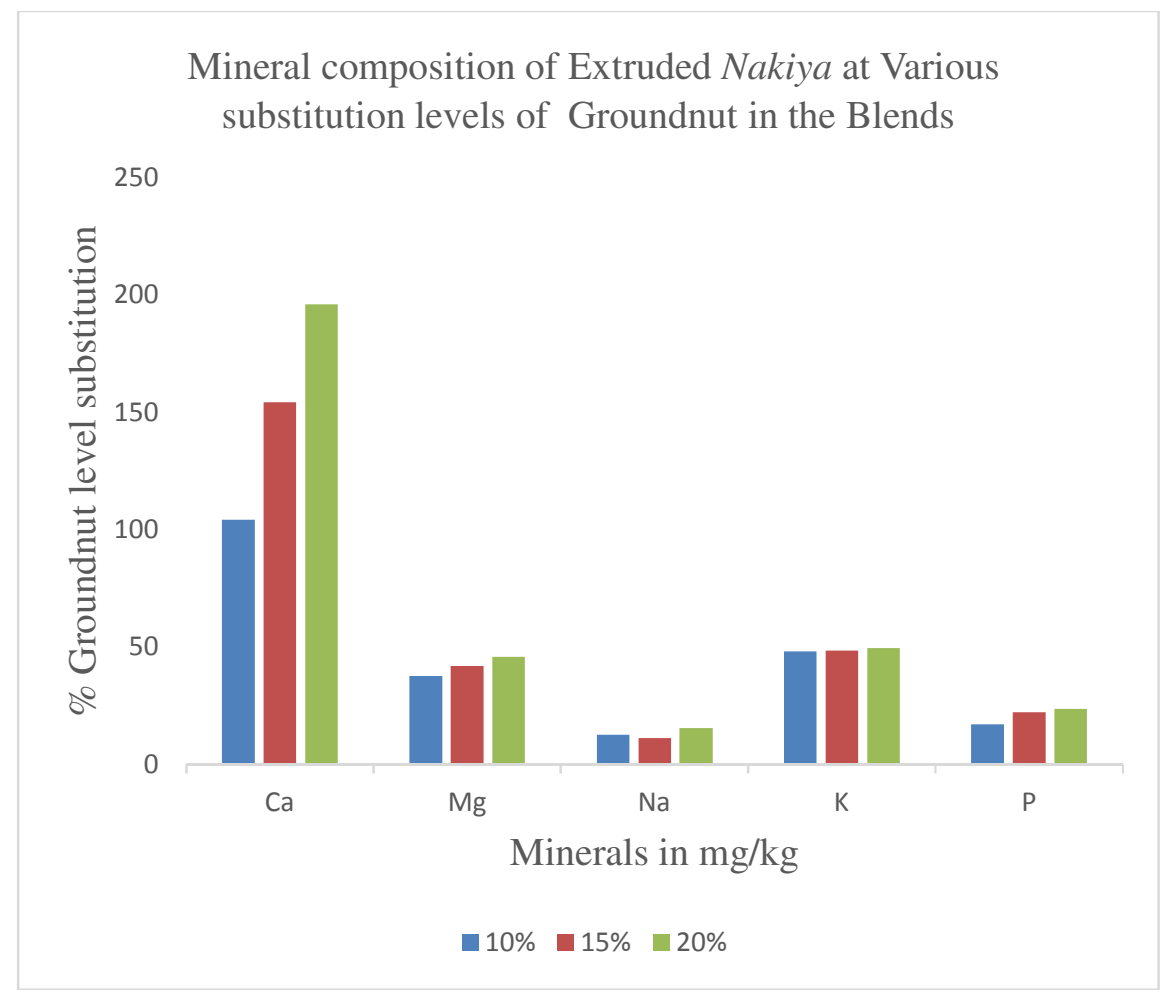

Fig 2 Mineral composition of Extruded Nakiya

Figure1 shows that the minerals content were high in extrudates containing high level of groundnut at $20 \%$ substitution levels. The Calcium content of the product ranged from $50-195 \mathrm{mg} / \mathrm{kg}$, Magnesium of $20.45-45.83 \mathrm{mg} / \mathrm{kg}$, Sodium with a value $5.56-15.29 \mathrm{mg} / \mathrm{kg}$, Potassium have25.52$49.48 \mathrm{mg} / \mathrm{kg}$ and Phosphorus content of $7.50-23.55 \mathrm{mg} / \mathrm{kg}$.

The highest calcium content of $195.83 \mathrm{mg} / \mathrm{kg}$ was from 80:20 flour blend of rice/groundnut, with $18 \%$ moisture content extruded at $80^{\circ} \mathrm{C}$, the value obtained was in contrast to the finding ofby Omwamba and Mahungu (2014) but in line with the report ofOluwoleet al., (2013). The value of Magnesium and Phosphorus was low in disagreement with $326 \mathrm{mg} / \mathrm{kg}$ and $2552 \mathrm{mg} / \mathrm{kg}$ found by James et al. (2016)

The high concentration of Magnesium, sodium, potassium and phosphorus were also high in extrudates with $20 \%$ groundnut substitution of groundnut, this goes in line with the finding of
Camira(2001) and Alonsoet al. (2000) that most of the Macro minerals are those that are affected upon extrusion.

\section{CONCLUSION}

It was discovered that the Nakiya extrudates were significantly high in protein with a decrease in carbohydrate at $20 \%$ substitution level of groundnut, low fat content in constrast to raw samples at $\mathrm{P}>0.05$. The minerals were also high at $20 \%$ levels of groundnut substitution, that is $80: 20$ rice/ groundnut blends. 


\section{REFERENCES}

Alonso, R., Grant, G.,Dewet, P. and Marzo, F. (2000). Nutritional assessment in vitro and in vivo of raw and extruded peas (PisumsativumL.).Journal of Agric Food Chem, 48(6):2286- 2290.

Asibuo, J.Y., Akromah, R.,Safo-kantanka, O.O. and Sei, A.H.(2008). Chemical composition of Groundnut, Arachis hypogaea (L) landraces. African Journal of Biotechnology.7(13):2203-2208.

Association of Official Analytical Chemists A.O.A.C. (1990). Official Methods of Analysis of 15th ed. Washington. DC.

Association of Official Analytical Chemists A.O.A.C. (2000). Official methods of Analysis, 16th ed. Washington. DC, USA.

Association of Official Analytical ChemistsA.O.A.C., (2006). Official methods ofAnalysis, 16th ed. Washington. DC, USA.

Atasie, V.N., Akinhanmiand,T.F. andOjiodu, C.C.(2009). Proximate analysis and physico-chemical properties of groundnut (Arachishypogaea L.).Pakistan Journal of Nutrition. 8:194-197

Ayo, J. A.,Onuoha,G.,Agu, H., Ayo, V. A.,Avu, E. O.,Sosanya, M. and Adesun, F.(2012).Effect of added beneseed paste on the quality of Millet based Masa.African Journal of Food Science and Technology.3(10):236-243.

Ayoola, P.B.,Adeyeye. A. and Onawumi, O.O.(2012). Evaluation of Food value of Groundnut (Arachis hypogaea) seeds. American Journal of Food and Nutrition $.2(3): 55-57$

Camire, M. E. (2001). Extrusion and nutritional quality. Extrusion Cooking.Pp108- 129.

Dibyankanta, S. Laxmikant, S.B., Vijayalakshmi, G. (2015).Effect of Feed composition, moisture content and extrusion temperature on the extrudate characteristics of Yam-Corn- Rice based snack food, Journal of Food Science and Technology. 52(3): 18301838

Dictionary.Com (2011). Definition of Snack.".Retrieved March 13, 2011.

Filli, K.B.,Nkama, I.,Jideani, V.A. and Abubakar, U.M.(2012). Effect of extrusion conditions on the Physicochemical Properties and Sensory Characteristics of Millet-Cowpea Based Fura European Journal of Food Research and Review. 2(1):1-23.

Folake, O.S., O.R., Ohwaseun, R. I.,Bolanle, O.O.(2015). Nutritional and sensory evaluation of Rice-based Masa enriched with soybean and crayfish. Journal of Food and Nutrition sciences.6:234-241

Guy, R.(2001). Extrusion Cooking. Technologies and Applications. Woodhead publishing company and CRS press

James, S. Nwabueze, T.U., Usman, M. A.,Samuel, O., Lilian N., James, Y.and Baba, I. A. (2016). Comparative study of the proximate and mineral compositions of extruded African breadfruit (Treculia Africana) mixwith some commercial pasta products. Journal of scientific research and report. 9(4): 1-9.

James, S. and Nwabueze,T.U. (2013).Quality Evaluation of extruded full fat blend of African Breadfruit- soybean-corn snack. International Journal of Food Science and Technology Research. 2 (9): 212216

Mukthar, A.A. (2009). Performance of three groundnuts (Arachis hypogeal L.) varieties as affected by basin size and plant population at Kadawa. Phd thesis submitted to post Graduate school, Ahmadu Bello University, Zaria.Pp17

Nuts - Healthy Tasty and High in Protein". (2011). Weightloss for all.com.

Nwabueze, T.U. (2006).Effect of hydration and screw speed on the nutrient and acceptability of extruded ready-to-eat African breadfruit Treculiaafricana) snack. Nigerian Food Journal. 24(1):107-113.

Obatula,V.A.(2002).Nutrient and sensory qualities of extruded malted or unmaltedMillet/Soybean mixture. Journal of Food Chemistry. 76: 129-133.

Ocheme, O. B., Ariahu, C.C., and Igyor, M. O. (2011).Assessment of traditionally produced Dakuwa (A cereal/legume based Nigerian snack) in Niger state, Nigerian Journal of Food Technology. 29(1): 63- 69.

Oluwole, O.B., Awonorin, S.O., Henshaw, Elemo,G.N.,

Bbuehi,O.A.T.(2013).Assessment of Microbial changes and Nutritional Qualities of Extruded white Yam (Dioscorearotundata) and Bambara groundnut (Vigna subterranean) blends. Journal of Food and Nutrition science. 4 (1): $100-107$ 
BAJOPAS Volume 12 Number 1, June, 2019

Omwamba, M. and Mahunga, S.M.
(2014). Development of a protein rich ready to eat Extruded snack from a composite blend of Rice, Sorghum and Soy flour.Food and Nutritional Science Journal.5:1307-1309

Oral Interview(2014). Traditional method of Nakiya production at Sangere, Yola state.

Riaz, M. (2013). Introduction to Extrusion. Presented at the ExtruAfrica Conference,"Need,Barriers and opportunities for extrusion in Africa", at Protea hotel Kruger Park, Skukuza Mpumalanga province, South Africa, August 1-2013
Shivendra, S., Shirani, G., Lara, W. (2007)."Nutritional aspects of food extrusion: A review". International Journal of Food Science and Technology. 42: 916-929

Wani, S.A. and Kumar, P.(2015).Effect of extrusion on Nutritional, Antioxidant and Microstructural characteristics of Nutritional enriched snacks. Journal of Food Processing and Preservation. 40(2):166-171.

Yousaf, M. (1992). Study on some physicochemical characteristics affecting cooking and eating Qualities of some Pakistani rice varieties. M.Sc. Thesis. Department of Food Technology, University of Agriculture Faisalabad, Pakistan. International Journal of Agric. Biology 10: 556-560 